\title{
10. Haemoglobin and Transferrin Polymorphisms in Some Turkish Native Sheep and their Several Crosses
}

\author{
By Mehmet Ihsan Soysal,*) Kazue TANAKa,**) and Shozo SuzukI**) \\ (Communicated by Shoei IsEKI, M. J. A., Jan. 13, 1986)
}

Electrophoretic variants of haemoglobin and transferrin were extensively studied on many sheep populations. Akagi (1974), Shimaoka (1981) reported protein polymorphisms of some European breeds of sheep in Japan. Although these genetic markers and their mode of inheritance were clarified in most sheep breeds, those for Turkish native sheep are rather limited. In this study it was tried to research for serum transferrin and red cell haemoglobin types in some Turkish native sheep, known to be highly polymorphic.

Breeds of some Turkish native sheep are Awassi and Mor Karaman. Both are very famous and popular in all over the world. The former is originated and raised in south-eastern Anatolia of Turkey and the latter is mainly raised in eastern districts of Anatolia.

Materials and methods. Blood samples were collected at random from 530 sheep of three different breeds; Awassi (I: 70 heads), Mor Karaman (K:96), Merinos ( M: 62) and their crosses; the cross breeds of Merinos and Mor Karaman (MK: 135), Merinos and Awassi (MI: 27), Mor Karaman and Awassi (KI: 36) and triple cross breeds of Awassi, Merinos and Mor Karaman (IMK: 104). Number of animals and abbreviation for populations are given in parenthes?s. Whole blood samples were collected from the external jugular vein to five mililiter tubes containing anticoagilant by venipuncture and separated to sera and erythrocytes immediately after sampling. Red blood cells and sera were separated by centrifugation for ten minutes at $1500 \mathrm{rev} / \mathrm{min}$ followed by removal of the sərum to the another tubes. Red blood cells were washed three times by adding four volume of $0.9 \%$ saline solution to one of erythrocytes. Haemolysates were prepared by lysing packed red cells with distilled water $(1: 1)$; and then sera and haemolysates were stored at $-20^{\circ} \mathrm{C}$ until electrophoretic studies. Sera and haemolysates were subjected to horizontal starch gel electrophoresis according to the slightly modified method described by Buchman and Schmid (1968); Dogrul (1973). Transferrin bands of serum and haemoglobin phenotypes in haemolysates were separated by horizontal starch gel electrophoresis in $160 \times 105$ $\times 4 \mathrm{~mm}$ gels casted on gel plates.

A continuous buffer system was used for the analysis of haemoglobin phenotypes. The gel composition which gave a total $100 \mathrm{ml}$ of starch gel concentration of about $10 \%$ consisted of $11 \mathrm{gr}$. hydrolized starch, $75 \mathrm{cc}$ distilled water and $25 \mathrm{cc}$ gel buffer. The electrode and gel buffer were contained $20.2 \mathrm{gr}$. tris, $2 \mathrm{gr}$. EDTA and $1.5 \mathrm{gr}$. boric acid in $1000 \mathrm{ml}$ of distilled water at $\mathrm{pH}$ : 8.7. Haemoglobin electrophoresis was employed to proceed for $1.5-2 \mathrm{hrs}$ at 350 volts.

\footnotetext{
*) Department of Zootechnical Science, Faculty of Agriculture, Ataturk University, Erzurum, Turkey.

**) Institute of Animal Serology, Tokyo University of Agriculture, Tokyo 156, Japan.
} 
A discontinuous buffer system was used for transferrin electrophoresis. Eleven gr. of hydrolized starch were used per $100 \mathrm{ml}$ of solution of gel buffer and distilled water $(1: 3 \mathrm{v} / \mathrm{v})$. The gel buffer was $9.2 \mathrm{gr}$. tris and $1.5 \mathrm{gr}$. citric acid in $1000 \mathrm{ml}$ of distilled water at $\mathrm{pH}: 8.2$. The electrode buffer was $18.54 \mathrm{gr}$. boric acid, $2.1 \mathrm{gr}$. sodium hydroxide in $1000 \mathrm{ml}$ of distilled water at $\mathrm{pH}: 8.0$. Transferrin electrophoresis was carried out at 350 volts for $3.5-4.0 \mathrm{hrs}$. After electrophoresis gels were sliced horizontally and stained for visible band by $0.5 \mathrm{gr}$. amido black $10 \mathrm{~B}$ in $230 \mathrm{cc}$ solution. Solution consisted of $400 \mathrm{cc}$ methyl alcohol, $400 \mathrm{cc}$ distilled water and $120 \mathrm{cc}$ acetic acid.

Genotypes and gene frequencies were estimated by direct counting method. The departure from genetic equilibrium was measured by means of the chi square test. The haemoglobin bands were interpreted by the methods of Ewans et al. (1956). Transferrin types were identified in order to their mobilities on starch gel.

Results and discussion. Five transferrin alleles $\left(T f^{A}, T f^{B}, T f^{M}, T f^{D}, T f^{E}\right)$ were recognized in whole population. Fourteen transferrin phenotypes consisting of four homozygotes (Tf-AA, Tf-BB, Tf-MM, Tf-DD) and ten heterozygotes (Tf-AB, Tf-AM, Tf-AD, Tf-AE, Tf-BM, Tf-BD, Tf-BE, Tf-MD, Tf-ME, Tf-DE) were detected from five alleles. A diagramatic representation of the transferrin phenotypes is depicted in Fig. 1 by the nomenclature of Rahman (1977). The distribution of gene frequencies (Table I) and Hardy-Weinberg equilibrium test of some sheep populations of eastern Anatolia were researched. Considerable variations were recognized in frequencies of transferrin alleles between populations. In all populations combined, the frequencies of $T f^{E}$ allele were found

Table I. Distribution of gene frequencies of transferrin and haemoglobin in some native sheep population of eastern Anatolia

\begin{tabular}{ccccccccc}
\hline \multirow{2}{*}{$\begin{array}{c}\text { Name of } \\
\text { allele }\end{array}$} & \multicolumn{7}{c}{ Population } \\
\cline { 2 - 9 } & $\mathrm{I}$ & $\mathrm{K}$ & $\mathrm{M}$ & $\mathrm{MK}$ & $\mathrm{MI}$ & $\mathrm{KI}$ & IKM & Total \\
\hline$T f^{A}$ & 0.210 & 0.395 & 0.172 & 0.233 & 0.288 & 0.309 & 0.248 & 0.263 \\
$T f^{B}$ & 0.340 & 0.227 & 0.204 & 0.200 & 0.327 & 0.309 & 0.342 & 0.264 \\
$T f^{M}$ & 0.150 & 0.189 & 0.265 & 0.200 & 0.154 & 0.142 & 0.143 & 0.178 \\
$T f^{D}$ & 0.210 & 0.174 & 0.348 & 0.339 & 0.192 & 0.217 & 0.228 & 0.255 \\
$T f^{E}$ & 0.090 & 0.015 & 0.011 & 0.028 & 0.038 & 0.023 & 0.039 & 0.040 \\
\hline$H b^{A}$ & 0.064 & 0.031 & 0.081 & 0.070 & 0.129 & 0.042 & 0.063 & 0.063 \\
$H b^{B}$ & 0.936 & 0.969 & 0.919 & 0.930 & 0.871 & 0.958 & 0.937 & 0.937 \\
\hline
\end{tabular}
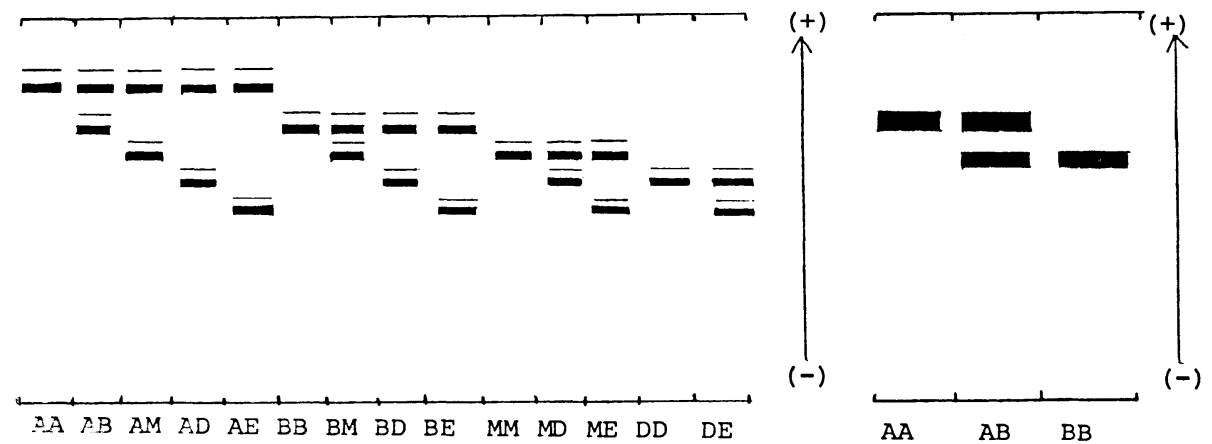

Fig. 1. Diagram of transferrin and haemoglobin bands. 
lowest, and frequencies of transferrin alleles were found to be $T f^{A}=0.263, T f^{B}$ $=0.264, T f^{M}=0.178, T f^{D}=0.255, T f^{E}=0.040$. The percentage of transferrin types was found to be highest $(12.20 \%)$ for Tf-DD and lowest for Tf-MM (1.26\%). In whole populations the percentage of homozygotes and heterozygotes types was $45.07 \%$ and $54.93 \%$, respectively. In some populations (Merinos, Merinos $\times$ Mor Karaman, Awassi $\times$ Merinos $\times$ Mor Karaman) the phenotypic values were not confirmed to values predicted on the basis of Hardy-Weinberg equilibrium. In all other breeds there were no significant differences between the observed values and the expected ones under genetic equilibrium.

Three electrophoretic haemoglobin phenotypes are recognized as shown in Fig. 1. Of 530 sheep, 2 had AA genotype, $63 \mathrm{AB}$ and $465 \mathrm{BB}$ in all populations. The gene frequencies are summarized in Table I. In all populations $H b^{B}$ gene was pre-dominant to $H b^{A}$. The type of $\mathrm{Hb}-\mathrm{AA}$ was not found in whole populations. The gene frequencies of $H b^{A}$ and $H b^{B}$ were 0.063 and 0.937 , respectively. There were no significant differences between observed and expected phenotypes under genetic equilibrium. Since the mode of inheritance of electrophoretic types of population couldn't be settled by this preliminary study, the conclusion about mechanism of inheritance couldn't be drawn.

In conclusion, these results confirmed the existence of polymorphism of transferrin and haemoglobin in some of eastern Anatolian native sheep breeds. This communication appears to be first publication on different genetic types of haemoglobin and transferrin in some of native sheep breeds of eastern Anatolia in Turkey.

Summary. Variants of serum transferrin and red cell haemoglobin in two native sheep breeds (Awassi and Mor Karaman) and purebreed of Merinos and their several cross breed populations were studied by starch gel electrophoresis. The frequencies of transferrin and haemoglobin phenotypes and their alleles were researched. Although the phenotype of $\mathrm{Hb}-\mathrm{AA}$ was very rare, all three haemoglobin types were clarified. Five transferrin alleles $\left(T f^{A}, T f^{B}, T f^{M}, T f^{D}, T f^{E}\right)$ were recognized in whole populations. Fourteen transferrin phenotypes consisting of four homozygotes and ten heterozygotes were recognized. Genotype and gene frequencies of each allele were demonstrated.

\section{References}

Akagi, S. (1974): Hemotypological Study of Sheep. Mem. of the Tokyo Univ. of Agric., vol. 16 , pp. $53-109$.

Buchman, H., and D. O. Schmid (1968): Serumgruppen Bei Tieren. Paul Parey in Berlin und Hamburg.

Dogrul, F. (1973) : TUBITAK IV Bilim Kongresi Tebligi. TUBITAK Ankara, Turkey (in Turkish).

Ewans, J. V. et al. (1956) : Nature, London, 178, 849-850.

Rahman, M. F. (1977): Doctorate Thesis. Ankara Universitesi Veteriner Fakultesi. Ankara, Turkey (Turkish with English summary).

Shimaoka, T. et al. (1981) : Relationship among six sheep breeds in Japan investigated from biochemical polymorphism. Japanese J. Zootech. Sci., 52(6), 413-418. 